Air temperature and water flow records show that during bright summer weather, the discharge of the river shows a marked diurnal variation. The maximum instantaneous discharge is roughly twice the minimum. The daily peak in discharge usually occurs 5-6 hours after the daily peak in the rate of ice melt. The time difference between the daily peaks in discharge and rate of melt seems not to be the same as the time taken for the water to travel through and underneath the glacier.

\title{
References
}

Larsen, L. 1970: The International Hydrological Decade programme in Narssaq river valley, South Greenland. Rapp. Grønlands geol. Unders. 28, 35-36.

UNESCO/IASH, 1970: Combined heat, ice and water balances at selected glacier basins. A guide for compilation and assemblance of data for glacier mass balance measurements. Tech. Pap. Hydrol. 5, 20 pp. Paris: Unesco.

\section{A PRELIMINARY DESCRIPTION OF THE KLOKKEN INTRUSION, SOUTH GREENLAND}

\section{Ian Parsons}

Klokken is a small $(3 \times 2 \mathrm{~km})$, Gardar igneous complex at $60^{\circ} 56^{\prime} \mathrm{N}, 45^{\circ} 05^{\prime} \mathrm{W}$. The intrusion is oval in form and the rock types are arranged in almost perfectly concentric fashion, an outer ring of gabbro giving way inwards via syenogabbros and basic syenites to a strikingly layered body of syenite. Quartz occurs in druses and in aplites and pegmatites, so that although the complex lies only $1 \mathrm{~km}$ south of the Igaliko nepheline syenites (Emeleus \& Harry, 1970), it is oversaturated and should not be regarded as a satellite of Igaliko. Klokken was visited in 1959 and 1960 by K. Ellitsgaard-Rasmussen in whose field notes many of the observations presented here may be found. The object of the 1971 field work was to obtain comprehensive specimen coverage, to look closely at the remarkable field relations and to extend the detail of the mapping.

The complex has sharp contacts with the surrounding Julianehåb granite and the existence of substantial protrusions, roof pendants and rotated xenoliths of country rock can be demonstrated. Hornfelsing and local mobilisation of the country rock has occurred.

\section{The gabbros}

An outer zone of gabbro up to $200 \mathrm{~m}$ wide forms a partial ring which broadens towards lower levels and is absent at high levels at the south-east margin. Fine- 
grained chilled gabbro is found at numerous contacts with country rock. Contacts and most structures within the gabbros, including xenoliths, are vertical or have steep outward dips.

The gabbro is characterised by tabular plagioclase crystals arranged in a crudely stellate fashion and in most sections seen, alkali feldspar is present as margins to plagioclase crystals. As the amount of alkali feldspar increases the tabular habit disappears and the rock gives way to coarse unlaminated syenogabbros and basic syenites, forming a strip up to $750 \mathrm{~m}$ wide adjacent to the inner layered syenite. Occasional, steeply inclined bands of granular syenite occur. Areas in the gabbros are frequently extremely coarse grained, giant plagioclases up to $50 \mathrm{~cm}$ in length appearing in a matrix of lesser grains, $5 \mathrm{~cm}$ in length. Some coarse-grained regions map as steep contact-parallel sheets, others as pods.

Irregular banded structures, mostly steeply inclined or outward dipping, occur in the gabbros. Some appear to show graded bedding, others resemble trough banding. However, at a locality NNE of the centre of the intrusion structures of this type can be shown to have opposing facing directions within about $10 \mathrm{~m}$. The layers occur as an alternation of material of coarse and fine type, and seem to have arisen by outward deposition of material on curved surfaces, after the manner of many zoned pegmatites. A related structure involves a network of wavy bands defining lenticular bodies of leucocratic material, perhaps $50 \mathrm{~cm}$ in length. EllitsgaardRasmussen called this "mackerel structure".

\section{The layered series}

The inner part of the intrusion, about $2 \mathrm{~km}$ in diameter, is spectacularly layered. It has the form of a pile of shallow, downward-pointing syenite cones. The inward dips are not constant but are normally between $30^{\circ}$ and $40^{\circ}$. The total thickness of the layered syenite reaches about $650 \mathrm{~m}$ in which 116 distinct horizons have been recognised.

Variation in the style of the layering at different levels makes generalisation unwise but a repeately observed relationship involving essentially two interleaved rock types is shown in fig. 4 . The most topographically pronounced bands are of brown-weathering, sugary-textured granular syenite, usually sparsely porphyritic, the alkali feldspar phenocrysts being randomly arranged. These layers, which make up about $15 \%$ of the succession, are separated by thicker units of coarser, often strongly laminated syenite, which is itself subject to repeated banding produced by variation in the proportion of feldspar to mafic constituents. At low levels biotite is often present in the mafic horizons, but at high levels the variation mainly involves concentrations of hedenbergitic pyroxene. The most extraordinary feature of these mafic layers is the repeated development of perfectly developed graded bedding, feldspathic syenite giving way upwards, characteristically over distances of about 2 $\mathrm{m}$, to an ultramafic top which may give way rapidly to leucosyenite or, as shown in fig. 4, may margin the base of a granular syenite layer. This "inverse" grading is 


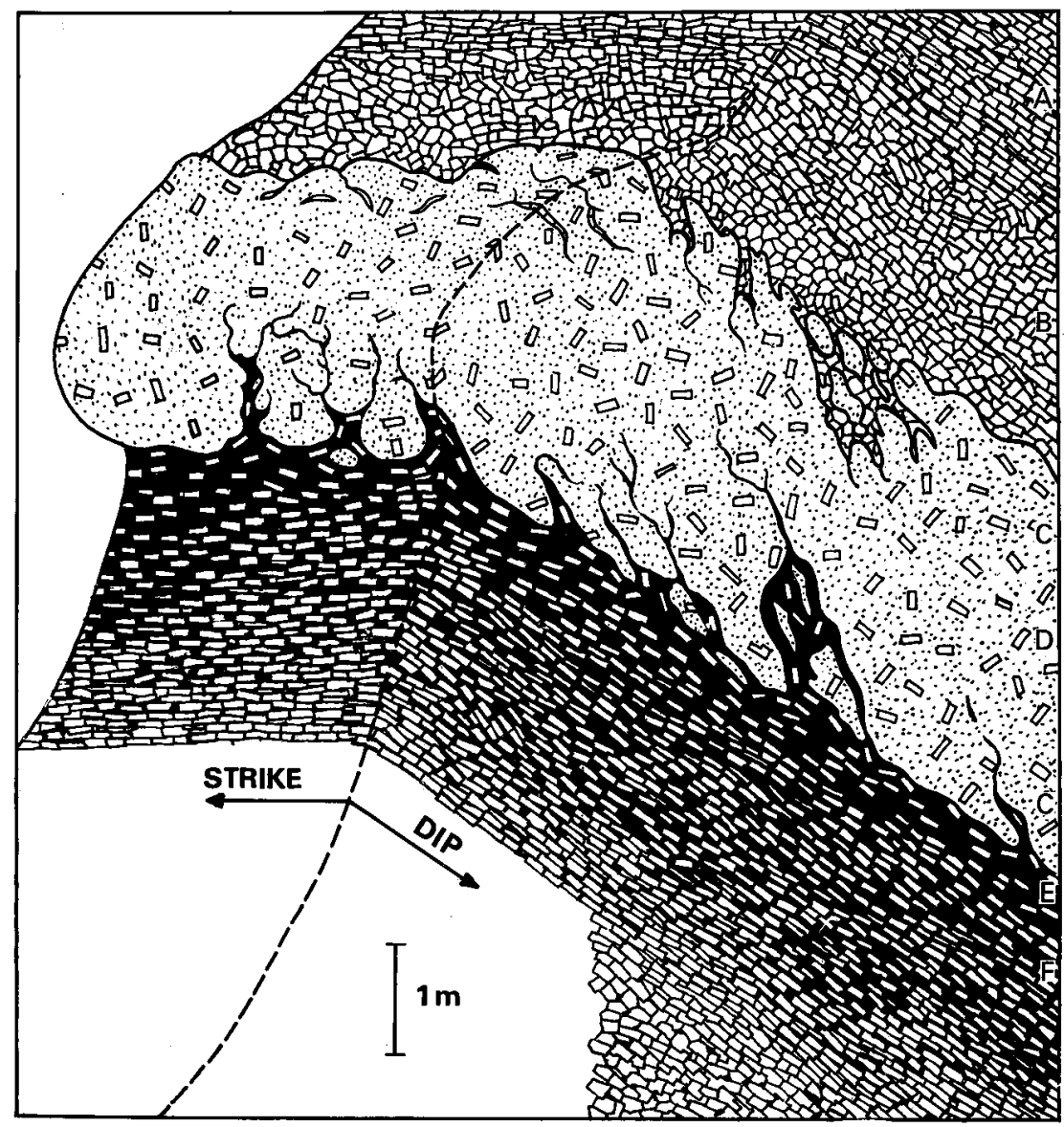

Fig. 4. Generalised block diagram illustrating the relationships in the layered series of the Klokken intrusion, South Greenland. While the relative size of the units is correct, the size of the feldspars is exaggerated by about 10. (Parsons). $A=$ laminated leucosyenite; $B=$ poorly laminated leucosyenite; $\mathrm{C}=$ zone of orientated apophyses; $\mathrm{D}=$ granular syenite; $\mathrm{E}=$ ultramafic top; $F=$ zone of 'inverse' grading.

unequivocally observed at 15 levels. Other mafic bands grade both up and down, but only three, very restricted instances, show distinct "normal" gradation.

An inversely graded unit near the top of the succession shows delicate rhythmic banding superimposed on the upward increase in mafics. False bedding can be seen and a shallow channel is infilled with material showing normal grading. The existence of these and other structures clearly indicates that crystal settling was the mechanism for the development of the mafic layers.

Some layers, of both granular and mafic type, can be traced along the strike for distances of up to $1.5 \mathrm{~km}$, but both types can also die out laterally, and many granular layers are impersistent breaking up into rafts or strings of xenoliths. Some 
$20 \mathrm{~m}$ thick granular units divide horizontally and become interleaved with laminated syenite. It seems that although there is some interrelationship between granular and mafic layers neither was essential to the development of the other.

The granular and laminated syenite layers have sharp but irregular contacts with a distinctive configuration (fig. 4). At intervals the granular layers are intruded by apophyses of laminated syenite, sometimes with pegmatitic material. Granular xenoliths, often in groups, frequently occur in the apophyses; where elongate these xenoliths show parallel steep dip. The feldspar lamination is always parallel to the contacts, flowing around the rounded surfaces of the granular layers and into the apophyses.

The granular and laminated layers are compositionally similar but not identical. The rounded surfaces of the layers suggest corrosion and the orientated apophyses are consistent with the injection of a mush of laminated syenite into fissures induced by loading combined with down-dip sliding of the layers of granular syenite.

\section{Late members}

In the highest part of the intrusion and to the NNW around the apparent focus of the layering, the layered series is cut by a discordant body of biotite syenite compositionally intermediate between the granular syenites of the layered series and the syenogabbros. This rock is distinguished by large poikilitic biotite plates. Towards the south-east it dies out as a dyke of comparable but finer grained material. The emplacement of this body has caused disturbance of the layered series, which are tilted and faulted, and west of the summit there is a mélange of granular syenite and biotite syenite.

This mélange and the layered series are cut by aplites of quartz syenite composition. Quartz-arfvedsonite and quartz-aegerine-bearing pegmatites also occur and in the upper part of the layered series quartz exists in druses. A few $060^{\circ}$ trending crush zones occur and in the east these are associated with reddening of the syenite. A few thin, trachytic dykes, of similar trend, cut the western part of the complex.

\section{Reference}

Emeleus, C. H. \& Harry, W. T. 1970: The Igaliko Nepheline Syenite Complex. General description. Bull. Grønlands geol. Unders. 85 (also Meddr Gronland 186, 3), 115 pp.

Dept. Geology \& Mineralogy, University of Aberdeen, Marischal College, Aberdeen, AB9 1AS, Scotland. 